\title{
The Local-Global Tendencies in Serbian Contemporary Architecture
}

\author{
Dijana Milašinović Marić, University of Priština \\ Igor Marić, Institute of Architecture and Urban \& Spatial Planning of Serbia
}

\begin{abstract}
The article considers the architectural works designed and realized in contemporary Serbian architectural practice in the context of questions and thinking about local-global but also of visible tendencies and dilemmas, that the architects deal with in smaller local environments like in Serbia, from the position of architectural historians, theoreticians and critics. The multi-layered, often vague double meaning and nuanced ties and interpretations of the mentioned relationships will be traced in the works of such important Serbian architects as I. Antić, M. Jovanović, B. Petrović, D. and M. Marušić, S. Krunić, I. Marić, B. Mitrović, I. Rašković, who were chosen in order to trace the line of development of the relationship between the local and global during $1950-2000$, the period which was also marked by turbulent social and political changes.
\end{abstract}

Keywords - Local, global, stimulus, multi-layered, Serbian architecture.

In order to answer the question: Where is a point in architectural design where local ends and global starts, or vice versa, how and what it stems from? we have to ask ourselves what is global related to local, national and traditional in the contemporary perception of the world. We will immediately notice that the term "globalization", as we perceive it today , is a relatively new one, linked to the second half of the twentieth century when pictures of luxury and wealth, easy life, big profits, and entertainment, continuous success and progress emerged all over the world in the time of the ascent of the high modernism and international style. As the concept of conquest, the globalization is much older. It is the main characteristics of the Western European culture starting from the Medieval ages, then catholic Portuguese and Spanish empires, crusades against and robbery of the nations of Islam and Orthodox nations, through western empires, first of all Britain. After the Second World War, America has taken precedence over the imposition of the globalisation process. Today, all countries adjust themselves to this ruling liberal paradigm. Numerous sociologists have reflected on the phenomenon of globalization which expanded especially after the breakdown of the last barrier - the Berlin Wall, erected in 1961, and destroyed in 1989, as the last symbol of the cold war and a part of the so-called Iron Curtain [2], [3], [10], [14]. In order to explain this phenomenon, appropriate is a sentence from the book Globalization and Its Discontents written by a Nobel Prize laureate in economics in 2001, Joseph Stiglitz: (globalization is) "closer integration of the countries and peoples of the world which has been brought about by (...) breaking down of artificial barriers to the flows of goods, services, capital, knowledge, and (to a lesser extent) people across borders." [10, 23]. Today the globalization is an overall process in the world trade and production, fashion, financial and economic market, migration flows, process of improvement of information and transportation systems, but also a process of negative flows of organized crime, terrorism, of an overall accumulation. All this indicates the at- mosphere predicted by the British writer George Orwell in his famous book 1984 (1949).

Globalization is an unstoppable process which is the result of general, accelerated technological development, breakdown of barriers through communication, social networks, and technology. Furthermore, in an encounter with different national ambiences, the globalization adjusts, changes, transforms itself, and its multicultural character is evident today. Because the local and regional cultural space responds to globalization with the reinterpretation of national identity, which, to some extent, supports overall cultural development and enables new (global and local) interaction as a source of cultural dynamics and cultural diversity [11]. The wave of globalization in architecture of the twentieth century was strongly felt in the process of expansion of international style in architecture when every cultural environment open to impacts more or less adopted itself to or in its own way interpreted the postulates of internationalism, thus incorporating the local experiences into new forms.

All European and world countries experienced the mentioned cultural and general trends in the period after the Second World War. At that time a part of Yugoslavia, with a special place in the socialist bloc at the crossroads between East and West both by its location and relatively independent policy, but also in the context of great need for development as it was devastated by the war, as well as in the context of the mentioned mondialisation processes, Serbia developed its own architecture. The state of flux between global and local, where the traditional was often proclaimed as retrogressive, i.e. something that is not leading to progress, has led to suppression, marginalization of own architectural values, resources, layers of history, as well as to the situation in which there has been no investments in everything that made Serbian space different and authentic, which is, however, imposed as a trend in the third millennium. Nevertheless, for the sake of the main characteristics of Serbian architecture, the attitude towards local, traditional, has remained alive, although asymmetrically placed.

The absence of stylistic unity and anti-dogmatic attitude to understanding of the general thesis of philosophy of modern architecture and its practical interpretation are the main characteristics of the post-war Serbian architecture $[9,111]$. This actually means that architects belonging to the Belgrade school of architecture have not accepted the original ideology of functionalism and international style in architecture out of the known reasons, but have always sought their own interpretations in architecture. Essentially, this is a specific form of resistance to any Orthodox perception, which is a basic vice and virtue of this school. Furthermore, in qualifying specificities of Serbian architecture, some have seen its anti-functionalist character which was ex- 


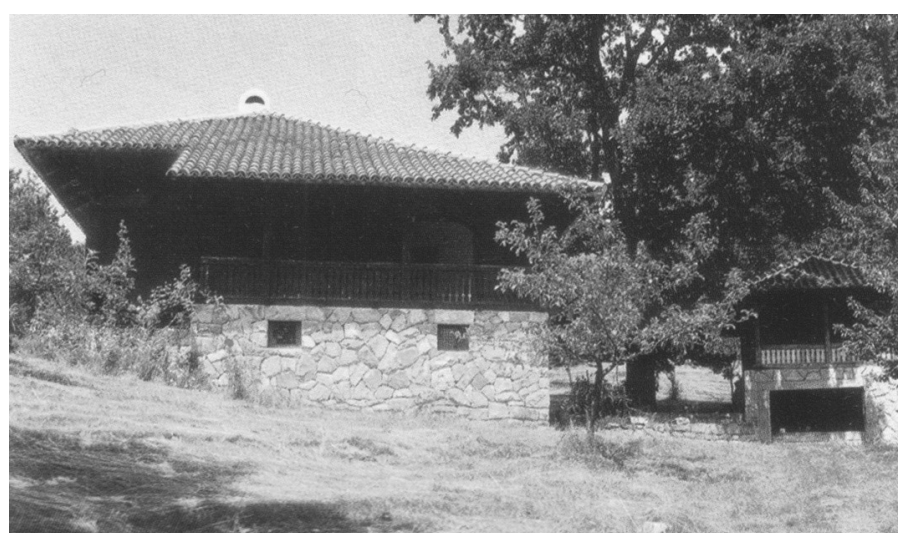

Fig. 1. House of architect B. Petrović. Boža Petrović [15].

pressed already in the fifties of the twentieth century. This anti-functionalism expressed through introducing the pictorial and semiotic elements into architecture is actually a specific anticipation of Postmodernism [1]. In addition to the marginalization of national values, the parallel trends of interweaving the global-international and local-traditional in activities of architects of different generations of the post-war Serbia can be traced through this very character of Serbian architecture as a whole. Herein, we shall mention only some examples.

\section{CONTEXT : ARCHitecture Works}

An important figure of Serbian post-war architecture who was faced with a dilemma of international progressive ideas and who committed himself to folk, local and traditional, is architect, Professor at the Faculty of Architecture of Belgrade, Bozidar Petrović (1922-2012). Architect Petrović has always believed that ancient folk architecture in Serbia has a value of tradition and that this tradition stems from primordial human needs. He believed that the house is not only a mechanical creation, but also by its naturalness, similar to a bird's nest or snail's shell. In the full sense, according to his opinion, a house should be human, which means something that is the content of man's life [8]. On the architectural map of Serbia in which a disturbed balance between the house, man and nature is evident today, the part of Serbia in which Boža Petrović designed the most, speaks in a particular way about substantial logics of preserving man's existence in space. The specificity of his houses, recognizable by the use of typical elements of traditional architecture in his works: hipped roof, porch and deep eaves, is that they are placed in the points of space which are the focuses of memory, the points which mark and radiate. Thanks to his works, mostly individual small buildings, the process of spoiling the landscape and ambience by inappropriate buildings has been stopped, thus affirming the attitude towards the multi-layered impact of architecture on space. He used to say: How to start from this traditional and authentic style - from inherited? Not formally, not by reviving some former pictures and moments, which would become a basis for some other form of artificiality, fake imitation and folklorism, but by reaching the contents of our time and space. Aren't we able to approach the heritage as a stimulating and productive

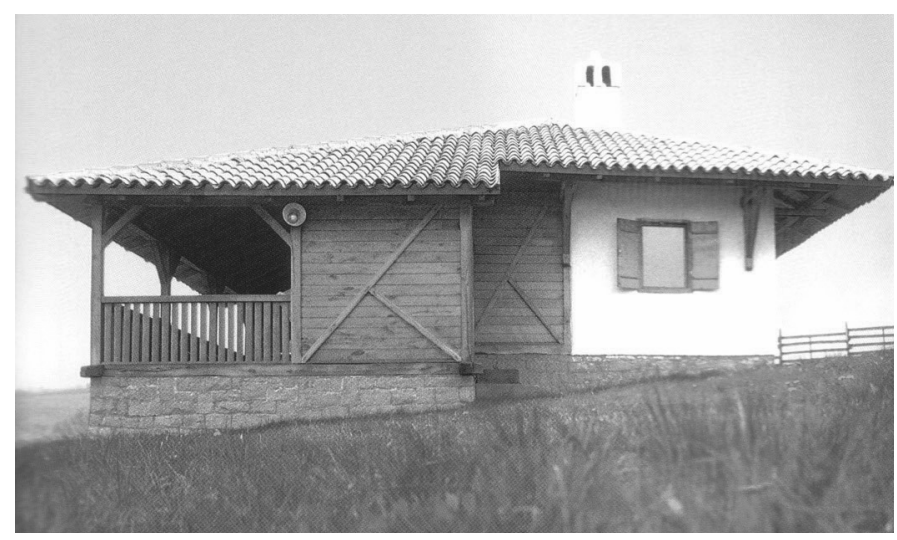

Fig. 2. House in Klatićevo. Boža Petrović [15].

model, and not as a relic? [8]. More than achieved harmony with the region, his houses are a reflection of the philosophical attitude that the preservation of traditional heritage is a prerequisite for identity of a nation (Fig. 1), (Fig. 2).

One of the most representative examples of public buildings where the national identity is expressed through the stylization of folklore elements is the building of the National Library of Serbia in Belgrade (1965-1973) designed by architect Ivo Kurtović (1910-1972). The building was of national importance also because during the German bombing of Belgrade in the Second World War on Easter, 6 April 1941, the building of the old library was burned to the ground, when over five hundred thousand books, magazines, old manuscripts, letters, maps, engravings, drawings, and pictures, were burnt in the fire. The stylized hipped copper roof with deep eaves on the concrete skeleton which covers architectural composition as a mantle is the main motif of the building. The identity of the Serbian house is underlined by spacious, shady porches along the side edges. A new, recognizable sight of Belgrade was created as its symbol, focus point and sign. Although in the time when it was built the building was criticized as being a retrograde work contrary to the modern trends, from today's position, it can be noticed that it is an extraordinarily brave and uncompromising work which, both in terms of urban planning and form, embodies the spirit of place through the stylization of architectural form in a unique and persuasive way (Fig. 3).

One of the most important Serbian architects, Professor and Academician Ivan Antić (1922-2005), with his extraordinary achievements in architecture in line with local-global, created masterpieces of Serbian architecture such as the Museum of Contemporary Art at Ušće in Belgrade (1965), Museum of Genocide, Šumarice in Kragujevac (1968-1975), sports halls, as well as commercial and public spaces. By his works he marked a period of timeless quality and originality. Considering his extensive work, it can be noticed that there are three directions in his architectural work: interest in stereometric abstract functional architectural form, then deliberations of traditional architecture and its primordial logics and simplicity of functional-visual composition, as well as the achievements in technology, i.e. the power of structure and large spans, particularly the blending of form and spatial forces into a single form. All 


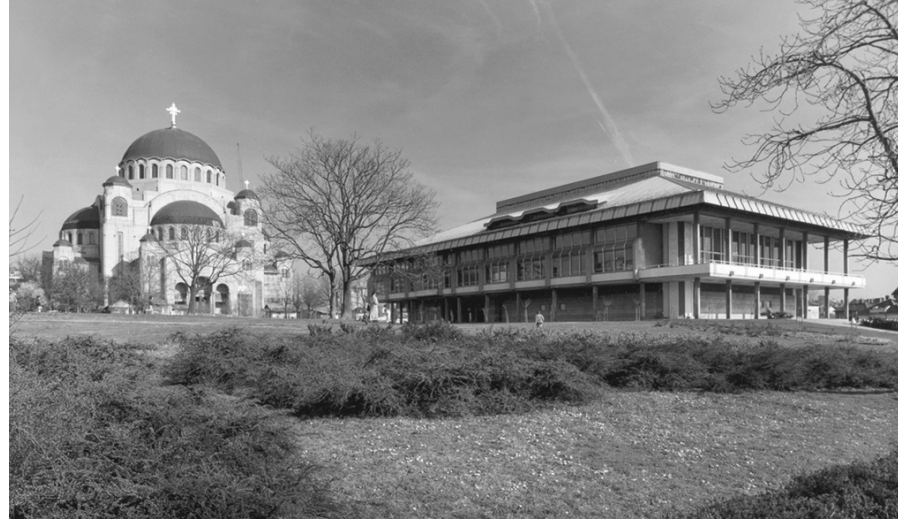

Fig. 3. National Library of Serbia. Ivo Kurtović, 1965 - 1973 [15].

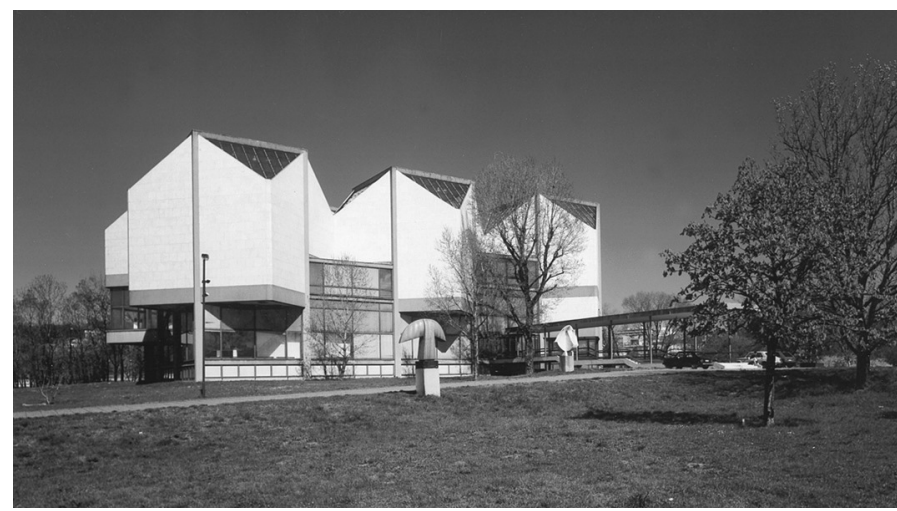

Fig. 4. Museum of Contemporary Art at Usce, Belgrade. Ivan Antić, 1961 1965 [15].

abovementioned directions did not develop independently, but overlapped, interwove, and were also summarized in a single whole having the value of a sign or a symbol. Exploring the abstract form, the pure geometric rational form, architect I. Antic together with his colleague I. Raspopović designed the Museum of Contemporary Art (1961-1965) (Fig. 4) at the confluence of the Sava and the Danube. This is an anthological work of Serbian architecture the basic value of which lies in its design, crystalline forms that can be multiplied in terms of function without disturbing the concept or idea, as well as in specific relationship towards its surroundings [6].

I. Antić also created a remarkable work which is a sublime of interaction between authentic folk and modern architecture, the "Politika" Cultural Centre in the small town of Krupanj (1976-1981) (Fig. 5) where he achieved ultimate harmony between traditional and modern by achieving a harmonic composition which blends into picturesque ambience of the valley between two rivers, thus recognizing, in addition to architectural elements, the importance of the place which the building should mark and in which it should radiate.

The ties with tradition, expressed associatively through archetypal codes, are also visible in his other buildings such as the complex of the 25 May Sports Centre in Belgrade (19711974), located on the Danube, close to its mouth, at the foot of the old Kalemegdan Fortress. The complex is designed in the bold architectural forms of sculptural charge and consists of two

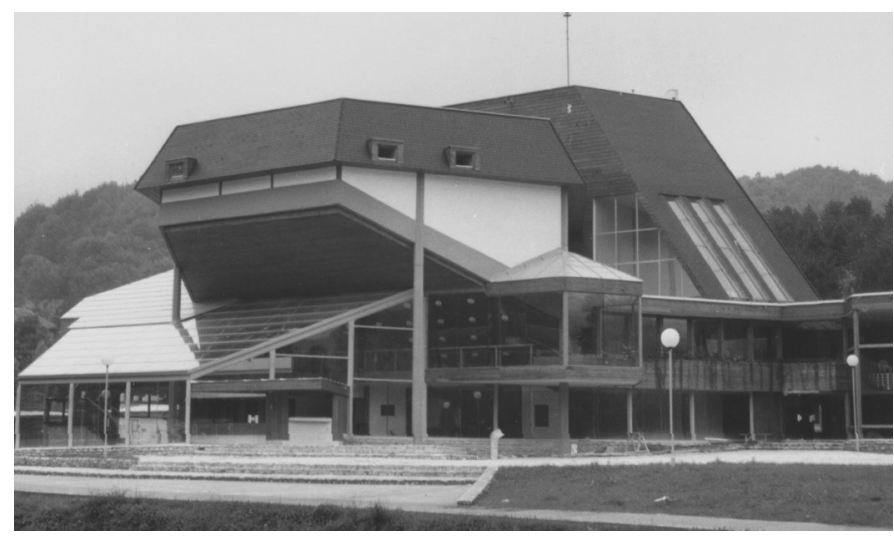

Fig. 5. "Politika" Cultural Centre, Krupanj. Ivan Antić, 1976 - 1981 [15].

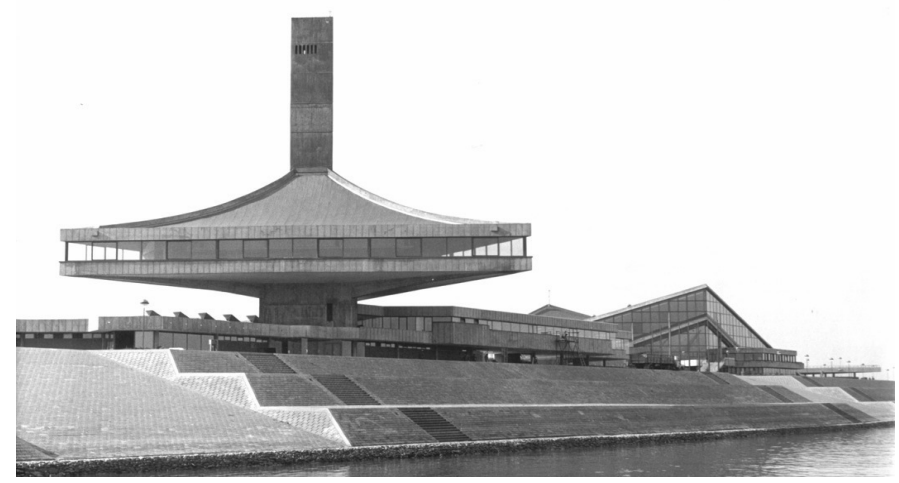

Fig. 6. 25 May Sports Centre, Belgrade. Ivan Antić, 1971 - 1974 [15].

bodies: restaurant placed in an impressive console over the river with a large-span roof and a concrete shell of the swimming pool hall in the form of hyperbolic paraboloid. Besides its shape that resembles a sail on a ship recognizable in the forms of the hall, the architectural structure of the restaurant resembles a traditional Serbian Morava style house: porch, roof, fireplace with chimney in the middle, and flexible interior space. Although it is a transposed form in which impact of brutalism in architecture is perceptible, it is clearly noticeable that the author was inspired by the semiocity from the Serbian traditional soil [5, 89] (Fig. 6).

Other authors of the next generations who worked in the period from the structuralism to the late modern dealt with the relationship between the global and local interpreting these impacts according to their sensibility. One of them was architect Svetislav Ličina (1932), a creator of a discrete suggestion, discrete guideposts, a master who committed himself to the exploration of the everyday and local in ambiences of cities and settings. His spaces are in an interaction with nature, along with the sense of proportion, with taste, glorifying the architecture. Due to this, these spaces survive, outgrow changes and live in the always new, still unexpressed, inner individual flows. To build means to cooperate with the soil, to put one's own mark in space, to contribute to gradual and slow changes in the life of a landscape and city [7]. The idea of forming such a well conceived space is clearly expressed in the new building of the 


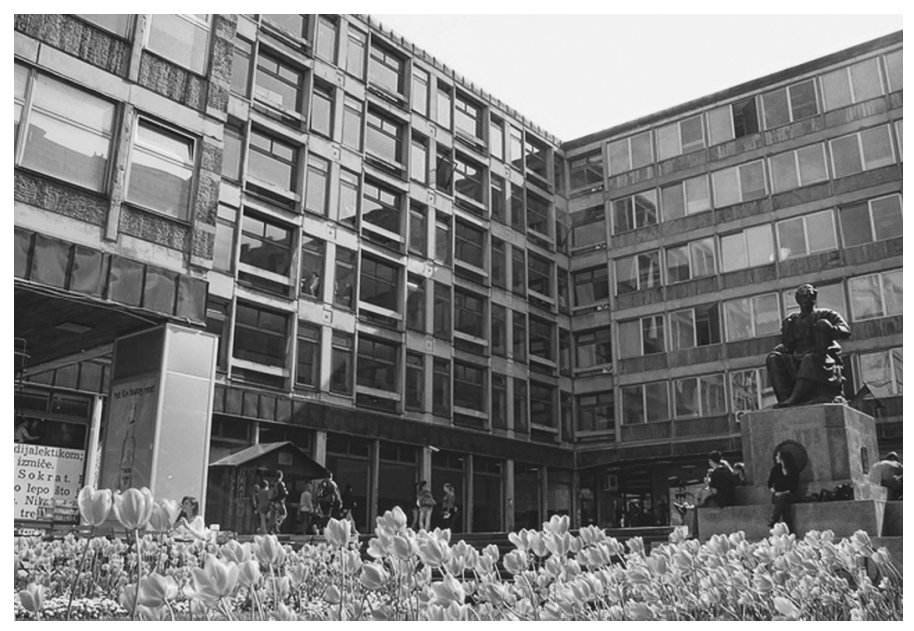

Fig. 7. Faculty of Philosophy, Belgrade. Svetislav Ličina, 1974 [15].

Faculty of Philosophy of Belgrade (1974). The Faculty building proves that architect Ličina has not only felt the maturity of architectural poetics, the existing space, local psychological and emotional qualities, but has also embodied them in an architectural form. The building successfully blends into the historical ambience of the city, while the bloodstream of the city with old buildings and small streets has flown into the newly designed building. The wings of the building form a newly opened, regular and accessible piazzetta which is, like a modern Agora - an academic square. This space confirms the essence of the square. It is entered through an access porch as a gathering place providing the opportunity for gathering and socializing, as well as different gatherings of the entire university (Fig. 7).

The architects of the younger generation who have appeared on the Serbian architectural scene in the post-modern period and whose architecture has encompassed a variety of trends and styles from the late twentieth and beginning of the twenty-first century have also expressed main characteristics of the Belgrade school of architecture: disharmony in taking over the models of international architecture, trying to find their own way in expressing the architectural attitudes. Considering turbulent times, economic crisis, break-up of the country, war, isolation, as well as the senseless and brutal NATO bombing, the conditions for creativity have been very limited, modest and extremely unfavourable. A new generation of architects born in the fifties of the twentieth century has grown up in such circumstances. They have created their own poetics in the local-global trend. Architect Igor Marić (1950) has, through numerous designs and realized solutions, built his own architectural language deeply rooted in modernism, but based on the roots of folk, primordial logic of architecture, particularly in the segment where a traditional builder has, besides functional assemblies, also used local materials and thought of healthy place, wind and sunlight duration. He has built in the bioclimatic and ecological aspects into his own experiences based on honesty and century-long experience in the construction of buildings. Such are his two unrealized designs, the ENECO-Centre in Budva (Fig. 8) and a new hotel in Banja Kanjiža spa (Fig. 9) (1996, 1998, together with M. Pucar), that are, by many specificities and both in the architectural and in urban concept, amongst his first considerations about bioclimat-

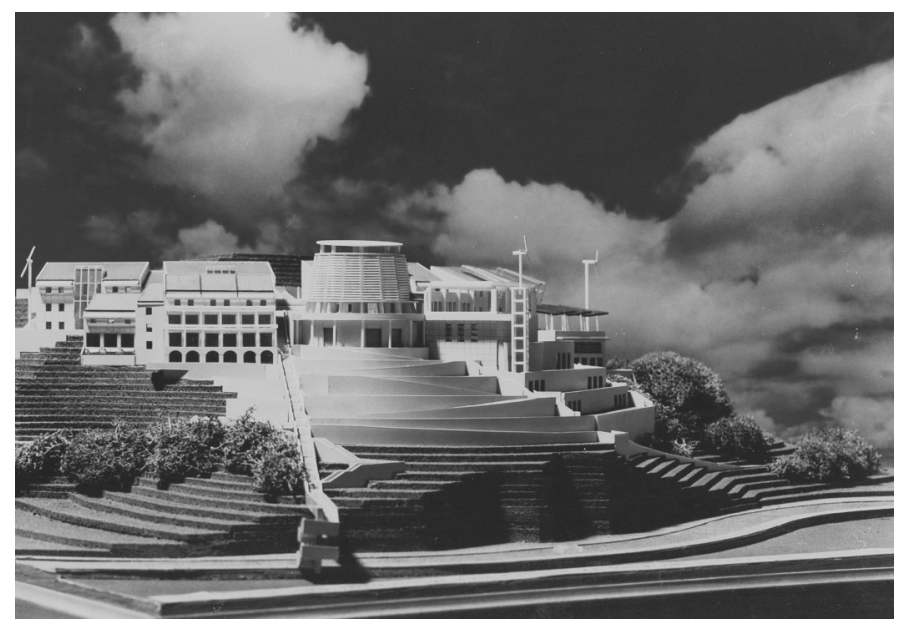

Fig. 8. ENECO-Center, Budva. Author 2, Mila Pucar, 1996 [15].

ic and ecological aspects in the Serbian architecture. These designs are a fresh blend of technological development and scientific concept of saving and use of new materials with the forms coloured with the local spirit, soil and characteristics of the region. The architectural concept follows the idea of the organic development of Paštrovićs (traditional) house, follows the terrain inclination in a non-aggressive way and takes into account the architectural tradition typical for this region [4, 57-61].

The works of one of the most important architects of the younger generation, Professor and Academician Branislav Mitrović (1948), reveal his thinking about double code. The relationship between the local and global, as today's paradigm, pervades his works, which is particularly recognized in the examples of sacral architecture. The conservative attitude that prevails in the Serbian Orthodox Church is that buildings should be modelled after the buildings of the Serbian-Byzantine-Morava traditional style and in accordance with the rigid canons of the past, so that the new, fresh ideas are difficult to penetrate. In designing and constructing the Temple of the Nativity of the Holy Mother of God in the village of Štipina near Knjaževac (2006 2011), architect Mitrović (together with architect Biljana Begenišić) have debated exactly these attitudes trying to achieve an architectural form which is not only a quotation or copy of old temples. The proportion of the building and the scale of the interior space of the temple are dimensioned relaying on the historical rules of construction. The contours and form are the same as the archetype of house or Christian places of worship because that creates a visual and mental link with the past, recognizable and familiar [13, 18]. Taking into account the strict liturgical canons and the temple interior organization, the authors have tried to create an artefact through visual association to archetypal Christian places of worship and recognizable texture of materials, which would be at the boundary between the past and the possible other (Fig.10).

Architect Ivan Rašković (1960), a member of the AGM team of architects who have, together with Blagota Pešić, built a New Dormitory of the Monastery of Banjska in Kosovo, Serbia, has dealt with the use of heritage in architecture and the issue of how to improve housing in the context of globalisation and $\mathrm{Eu}-$ ropean integration. In its basic concept and architectural design, 


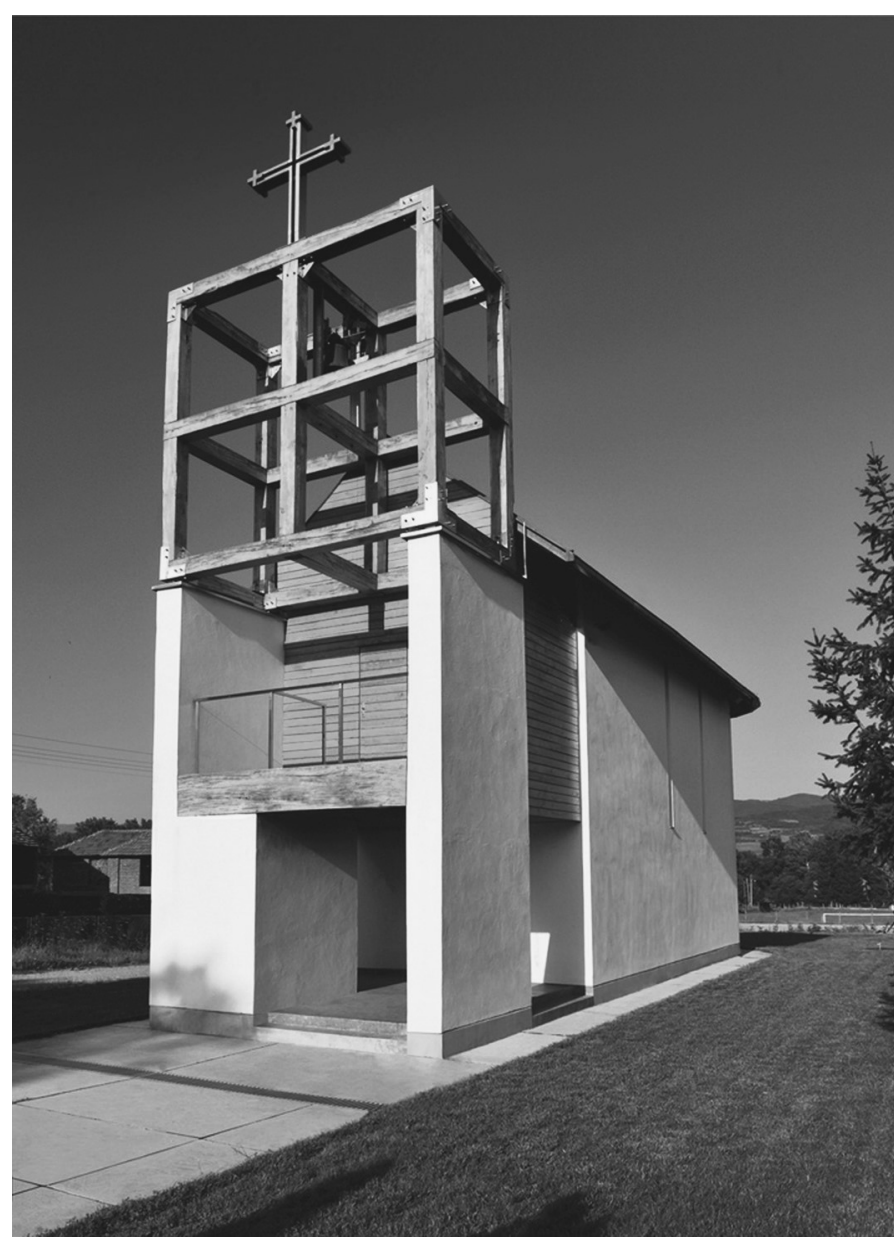

Fig. 10. Temple of the Nativity of the Holy Mother of God, Village of Štipina near Knjaževac. Branislav Mitrović, Biljana Begenišić, 2006-2011 [16].

this building summarizes several levels of meaning of messages, associations, with the aim to achieve a spatial metaphor at several levels, taking into account the place which Kosovo occupies in the creation of the country in the memory of Serbian nation. By the design and the used materials, essentially by a structural method, the new building revives memories, the local, the spirit of space, history, and is a link between the past and present, thus achieving the spatial-temporal relationship within the continuity of life in the Monastery, and underlines that architectural works should be conceived as a paradigm of the system of cultural and social values of a certain community [12, 108-117] (Fig. 11).

\section{CONCLUSION}

With relation to local-global, the process of reinterpretation of natural culture through social reactions and interpretations that has begun in the first decades of the second half of the twentieth century has led to the exclusion of the local national identity as marginalized with relation to the global trends. But, exactly because of the character of globalisation where isolation is not possible, in the spiral circle, with the emergence of the European post-modern and at the end of the twentieth century, the trend of reinterpretations of national has begun with overcoming the

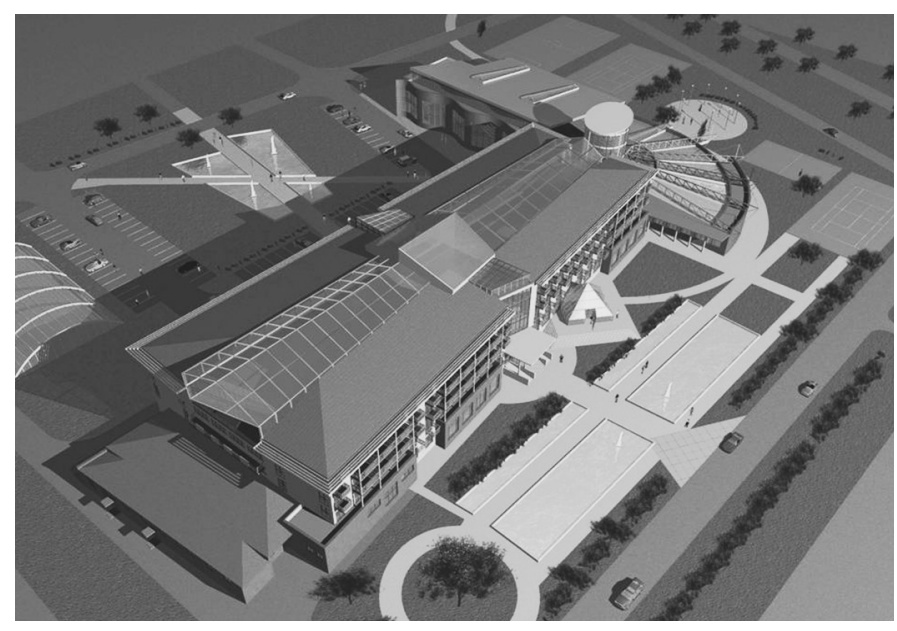

Fig. 9. Banja Kanjiža spa. Author 2, Mila Pucar, 1998 [15].

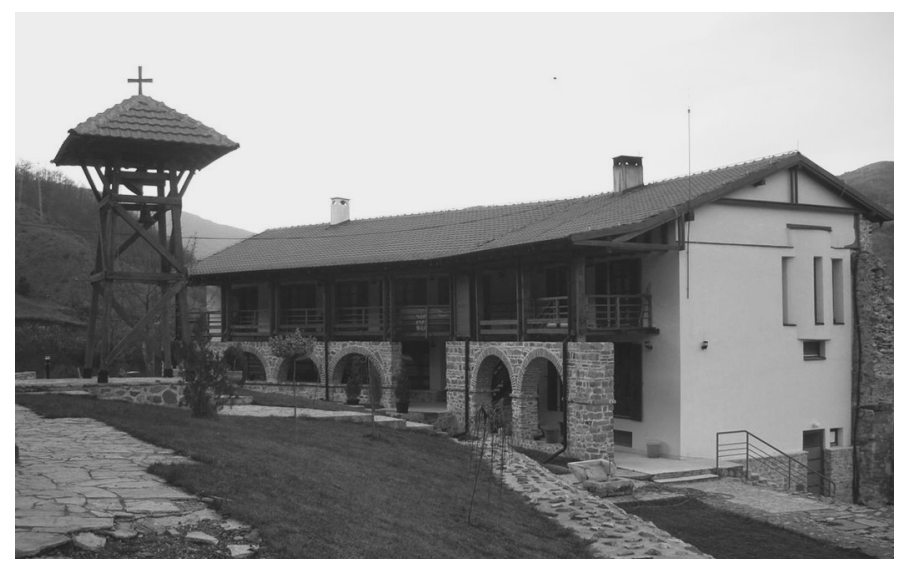

Fig. 11. New Dormitory of the Monastery of Banjska in Kosovo. AGM and Blagota Pešić, 2004 [17].

barriers where the impetus is being sought in national heritage, and the impulses are recognized in local and professional specificities which will again change the existing definition of identity and values produced by such interactive relationship. In this phase of globalization which draws strength from the multicultural, it is the recognition of these processes and a nuanced relationship between them that could be the first and stimulating path to solving the growing opposites but also to the preservation of the diversity as a stronghold of identity which is so necessary to man. Such a starting point is ever more important in the smaller and poorer environments that are craving for achieving the prestige through architectural megastructures offered to them by the world top architectural teams whose main preoccupation is to build as unusual forms as possible as a result of technological progress and new materials, the forms that often do not have a foothold in local ambience, do not take into account a man as the measure of all things, and which are inappropriate. In the world of architecture, culture and art, it appears that, exactly in the space of the nuanced communications between global trends and intricate, interwoven local-traditional-national relationships, as well as the positivistic attitude to the open path, it is possible to continually build the general in individual, universal in local, like an endless spiral. 


\section{REFERENCES}

1. Brkić, A. Znakovi u kamenu, Srpska moderna arhitektura 1930-1980. Beograd: SAS, 1992, 231 str.

2. Č́omski, N. Svetski poredak stari i novi. Beograd: SKC, 1996.

3. Hantington, S. Sukob civilizacija. Beograd: CID, 1999.

4. Marić, I., Pucar, M. Mediteranski centar za energiju i ekologiju, ENEKO - centar i centar za multidisciplinarne studije i istraživanja u Budvi (ENECO-CENTRE, Mediterranean Centre for Energy and Ecology and Centre for Multidisciplinary Studies and Research in Budva), Arhitektura i urbanizam, 1996, No. 3, str. 57-61.

5. Marić, I. Tradicionalno graditeljstvo Pomoravlja i savremena arhitektura. Beograd: IAUS, 2006, 89 str.

6. Milašinović Marić, D. Disciplina arhitekture $i$ sloboda duha, arhitekta Ivan Antić (Discipline of Architecture and Freedom of Spirit, Architect Ivan Antić), script for TV episode of the serial "Srpska moderna arhitektura, ličnosti i poetike" ("Modern Architecture in Serbia, Personalities and Poetics"), RTS Second Channel, Belgrade, broadcast on 22 May, 2002.

7. Milašinović Marić, D. Građenje kroz vreme, arhitekta Svetislav Ličina (Architecture through Time, Architect Svetislav Ličina), script for TV episode of the serial "Srpska moderna arhitektura, ličnosti i poetike" ("Modern Architecture in Serbia, Personalities and Poetics"), RTS Second Channel Belgrade, broadcast on 24 June 2002.

8. Milašinović Marić, D. Moć blagorodnog, arhitekta Božidar Petrović (The Power of Authentic Tradition, Architect Božidar Petrović), script for TV episode of the serial "Srpska moderna arhitektura, ličnosti i poetike" ("Modern Architecture in Serbia, Personalities and Poetics"), RTS Second Channel Belgrade, broadcast on 12 January 2004.

9. Stojanović, B. Martinović, U. Beograd 1945-1975 : Urbanizam-arhitektura. Beograd: NIRO "Tehnička knjiga“, 1978. 247 p.

10. Štiglić, Đ. Protivrečnosti globalizacije. Beograd: Socijalna misao, 2002.

11. Švob-Đokić, N. Kraj globalizacije i kulturni razvoj. Zagreb: Zarez, 2006.

12. AGM Studio (Đulinac, M. Petrović, B. Rašković, I. et al.). Novi konak manastira Banjska. Forum+, 2004, 49, str. 108-117.

13. Urošević, M. Mitrović, B. (ed.) Hram rođenja Presvete Bogorodice, Štipina 2006-2011. Beograd: Arhitektonski fakultet, 2011.

14. Vidojević, Z. Kuda vodi globalizacija. Beograd: Filip Višnjić, 2005.

15. Photo archive of the authors.

16. Photo archive of architect Branislav Mitrović [online, cited 10.09.2014] www.mitarh.rs/index.php? $\mathrm{p}=$ branislav-mitrovic

17. Photo archive of AGM studio [online, cited 10.09.2014]. www.agm.rs/index.php?option=com

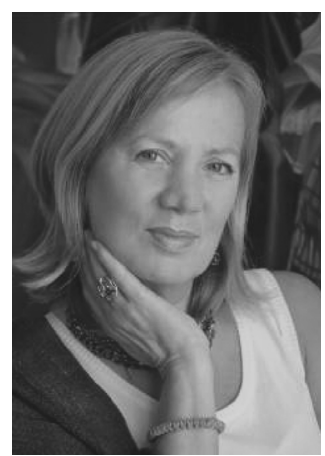

Dijana Milašinović Marić received her $\mathrm{PhD}$ in History of Arts from the Department of History of Art of the Faculty of Philosophy of Belgrade. She is a Professor with the Faculty of Technical Sciences and Architecture in Kosovska Mitrovica where she lectures on History of Modern Architecture and Urban Planning, History of Art, Architecture Today, Synthesis of Architecture and Art, and History of Architecture and Settlements in Serbia.

She is the author of books (Architecture of Jan Dubovi, Guide to Modern Architecture of Belgrade, 2002) and over 200 professional and scientific papers. She is the author of scientific -

educational serials of the RTS (Radio Television of Serbia): Modern Architecture in Serbia, Personalities and Poetics (11 episodes), Ars Practica (50 episodes) on fine art and artists of applied art of Serbia, and, based on her book, the Guide to Modern Architecture of Belgrade, a serial of 14 episodes.

Since 2007, she has been a member of the Professional Editorial Board of the Serbian Encyclopaedia of Fine Arts and Architecture, a member of the Editorial Board of the Glossary of Art Terms, publisher: Serbian Academy of Sciences and Arts.

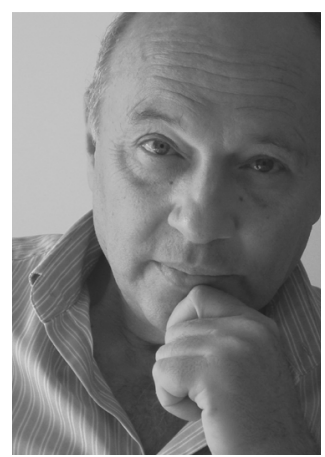

Igor Marić received his $\mathrm{Ph} . \mathrm{D}$ from the Faculty of Architecture. He is an architect and is engaged in scientific work, planning, design and education. His research interests are bioclimatic architecture and relationship between vernacular and contemporary architecture of Serbia.

Igor Maric is Director of Institute of Architecture and Urban \& Spatial Planning of Serbia, President of the Association of Architects of Serbia and Vice President of the Union of Engineers of Serbia. He has received many awards at a number of architecture and town planning competitions, as well as professional recognitions amongst which is the recognition of exceptional achievements in the profession by the Chamber of Engineers of Serbia. Besides his professional activities, he has also been actively involved in professional associations of architects, town planners and engineers, he has written for professional magazines and daily newspapers. Igor Marić is also an associate member of the Academy of Engineering Sciences of Serbia.

\section{CONTACT DATA}

Dijana Milašinović Marić

Faculty of Technical Sciences, University of Priština in Kosovska Mitrovica, Kneza Miloša No. 7, 38220 Kosovska Mitrovica, Serbia

Phone: +381642237003

E-mail: dijanam.maric@gmail.com

Igor Marić

Institute of Architecture and Urban \& Spatial Planning of Serbia (IAUS)

Bulevar kralja Aleksandra 73/II, 11000 Belgrade, Serbia

Phone: +381 113370182

E-mail: igor@iaus.ac.rs 